\title{
Yield performance and agronomic efficiency in oil pumpkins (Cucurbita pepo L. group Pepo) depending on production systems and varieties
}

\author{
Manfred JAKOP*, Silva GROBELNIK MLAKAR, Martina BAVEC, Martina ROBAČER, \\ Tjaša VUKMANIČ, Urška LISEC, Franci BAVEC \\ University of Maribor, Faculty of Agriculture and Life Sciences, Pivola 10, 2311 Hoče, Slovenia
}

\begin{abstract}
In 2013 and 2014, a long-term trial (which was established in 2007) was conducted at the University Agricultural Centre in Pivola near Hoče. It included different production systems (conventional, integrated, organic, biodynamic), carried out in a field trial with oil pumpkins. The aim of the research was to analyse the effects of different production systems, varieties (hybrid and population variety) and years of production, on formation of oil pumpkin yields. The agricultural practice has been carried out in accordance with the applicable legislations and standards for the individual production system. When sowing, before fertilizing with nitrogen in early June and after the harvest, the amount of soil mineral nitrogen was monitored. We evaluated the number and weight of harvestable, unripe and decayed fruits, and yield of oil seed pumpkins and calculated the agronomic efficiency of the applied nutrients. The results showed that the year of production, the production system and the variety have a significant effect on some fruit characteristics and the yield of oil pumpkin seeds. The content of soil mineral nitrogen in May and September was significantly influenced by the production system and the year. In June, only the production system had a significant effect. The hybrid significantly increased the yields of oil pumpkin seeds in all production systems, even in the year that was less suitable for production. The agronomic efficiency of the applied nutrients in the biodynamic and organic production system is higher or equal than in the conventional production system, similarly, agronomic efficiency is higher in the hybrid compared to the oldest population variety efficiently. A comparable oil pumpkin yield can be expected in biodynamic and organic production, when proper nutrition and well carried out cultivation practices are combined with a new variety, when compared to less sustainable production systems, which often cause damage to the environment.
\end{abstract}

Key words: production systems, variety, oil pumpkins, mineral nitrogen, agronomic efficiency, yield.

\section{INTRODUCTION}

Different agricultural production systems (PS), such as conventional (CON), integrated (INT), organic (ORG) and biodynamic (BD) farming, have different impacts on the environment, preservation of landscape and soil fertility (Wall et al. 2015). Agriculture has to provide food for an everincreasing population, estimated to grow up to 10 billion in 2050, which will further intensify the production systems and increasingly impact the environment (Pingali 2012, Smith et al. 2013).

Consumer concern regarding possible adverse health effects of products and foods produced by intensive farming methods has led to a considerable increase in interest in the health benefits of organic production systems (ORG, BD). Nowadays, consumers expect a minimal environmental impact of PS and food produced in a way, that not only satisfies all their nutritional needs, but also positively impacts

${ }^{*}$ Correspondence to:

E-mail:manfred.jakop@um.si 
their health (Goetzke et al. 2014). Some authors (Specht et al. 2014, Touliatos et al. 2016, Muller et al. 2017) see the future of solving food and environmental problems in intensifying conventional farming and upgrading it to vertical farming or high-tech farming. Vertical farming offers a higher production yield with a growth index of 10 to $100(\mathrm{CON}=1)$ in soil-less food production, low area use, very high-energy use (energy may be used from alternative sources), with low nitrogen losses, a controlled but poor biodiversity and high financial input and profit.

Convectional farming, which is the second biggest environmental polluter, is being increasingly criticised by the public, who demand a sustainable way of producing food, which does not include GMO or the use of synthetic materials (Bavec et al. 2009). Sustainable production systems guarantee agricultural products free from pesticide residue and other unwanted substances (Williams and Hammitt 2001), and with them less pollution of the environment. By applying soil biodiversity, they also provide benefits to human health because soil biodiversity can suppress diseasecausing soil organisms and provide clean air, water and food, where conventional farming reduces all those benefits (Wall et al. 2015).

Quite a few studies comparing conventional and organic field crop production have been conducted lately (Connor 2008, Seufert et al. 2012, Meier et al. 2015, Shah et al. 2017), as well as studies comparing integrated and organic ways of production (Deikea et al. 2008, Muller et al. 2011, Nemecek et al. 2011), or comparisons among several PS (Pfiffner and Mäder 1997, Turinek 2011, Štraus 2012). The authors came to different conclusions concerning plant material and the applied agronomic measures. The effectiveness and appropriateness of the PS can be measured in different ways. Indicators of environmental influences like ecological footprint (Vukmanič 2016), consumed energy per area (Deikea et al. 2008) or the amount of yield per hectare (Turinek 2011) have been mentioned in the literature. The success indicator of a production system can also be the yield's response to the amount of applied nutrients (Fixen et al. 2015). That can be measured by the agronomic efficiency (AE) of $\mathrm{N}, \mathrm{P}$ or $\mathrm{K}\left(\mathrm{AE}_{\mathrm{N}}, \mathrm{AE}_{\mathrm{P}}\right.$ or $\left.\mathrm{AE}_{\mathrm{K}}\right)$, which results in the increase of yield in $\mathrm{kg}$ per $\mathrm{kg}$ of applied fertiliser $\left(\mathrm{N}, \mathrm{P}_{2} \mathrm{O}_{5}\right.$, $\mathrm{K}_{2} \mathrm{O}$ ). $\mathrm{AE}$, in connection with estimated yield response, is becoming an important alternative indicator for supporting crop fertilization in some countries (Chuan et al. 2013, Zhou 2013).

There is very little research on the effect of PS on growth, development and yield of oil pumpkins (Cucurbita pepo L. group Pepo) in a sub-continental temperate climate in long-term experiments (Turinek 2011). The production of pumpkin seeds for oil is present in some European countries, the traditional producers being Slovenia, Austria, Hungary, Croatia and Serbia (Bavec 2000). A small portion of production is also starting to emerge in the Check Republic and Ukraine (Jariene at al. 2007). In Slovenia, oil pumpkins are produced on an area of 5410 ha, which is the biggest surface among oil plants (SURS 2017) and plays an important part in field crop rotation. The marketing of oil pumpkins and their products provides an important source of income for farms. Different production systems enable the producers to choose among different approaches of production, which includes changing up some of the techniques of production. Those may include using different overwintering and nonoverwintering cover crops in strip till belts (Jakop 2010), or a combination of cover crops and roller crimpers (Bavec at al. 2014). Regardless of production system, a successful oil pumpkin production requires a well-chosen location, which has to be rich in humus, nutrients, sunlight and has a low weed population (Bavec and Jakop 1994, Kocjan Ačko 2015). The quantity of yield, regardless of production system, can be connected to the amount of $\mathrm{N}$ the production system receives either through mineral fertilizers (CON, INT), organic fertilizer (animal manure), compost or cover crops (ORG BD). Organic production systems, in comparison with other conventional production systems, can only be efficient, if the conditions in the soil do not hold back the mineralization of $\mathrm{N}$ and other nutrients (micro and macro elements) that need to be at the disposal of the root system during a plant's intensive growth periods (Berry et al. 2002). The results of a meta-analysis (Seufert et al. 2012) show that when good management practices are applied, organically produced oleaginous plant yields are only less than $10 \%$ smaller than those produced in conventional production systems. In our long-term study, the results of pumpkin seed yield and the yield components were compared in two consecutive years.

The aim of the study was therefore to analyse the effect of the PS (biodynamic, organic, integrated and conventional) and the type of pumpkin variety (hybrid and population variety) on the characteristics of the fruit, the mineral nitrogen in the soil in different growth stages, the agronomic efficiency of added nutrients, and their connection to seed yield. The goal was to compare the adequacy of the oil pumpkin production in different production systems.

\section{MATERIALS AND METHODS}

\section{Long-term field trial}

The oil pumpkin field trial started in May 2013 in the seventh growth season of the long-term field trial located at the University Agricultural Centre of the University of Maribor in Pivola near Hoče ( $46^{\circ} 28^{\prime} \mathrm{N}, 15^{\circ} 38^{\prime}$ E, $282 \mathrm{~m}$ above sea level). The experiment was arranged in a randomized complete block design in split-plots with four replicates. The size of each experimental plot was $29.4 \mathrm{~m}^{2}$ (7.0 m long $\times 4.2$ $\mathrm{m}$ wide). The distances between the rows were $1.4 \mathrm{~m}$ and about $0.6 \mathrm{~m}$ ( 12 seeds per row) within the rows.

The experimental design involved two factors. The first was four different production systems (conventional - CON, integrated INT, organic - ORG, biodynamic - BD) and control plots (without plant protection or added nutrients)). The second factor involved two oil pumpkin varieties known for their production in Central Europe, namely hybrid (HY) and population variety (PV). The agricultural practices in the PS in oil pumpkins are shown in Table 1. Soil tillage, sowing and harvesting were similar among experimental plots. The production in the different PS differed in type and amount of fertilizer with the approximately same amount of nutrients, plant protection and weed control, and was performed on the 
same dates and in a similar manner than the adjacent fields.

Agricultural practices in specific production systems were carried out according to the legislations and standards in effect during 2013 and 2014 for organic farming (EC 834/2007 2007, ES 889/2008 2008, MKGP 2006, 2008, 2014a), biodynamic farming (Demeter International e.V. 2012), conventional farming (MKGP 2008, 2012a, 2012b, 2014a) and integrated farming production (MKGP 2010, 2013, 2014b).

Basic fertilizing with manure (ORG) and composted manure (BD) was carried out in an amount of $22 \mathrm{t} / \mathrm{ha}$. Additional fertilizing on both plots was carried out using ground pumpkin cakes. $560 \mathrm{~kg} / \mathrm{ha}$ of pumpkin cakes with $9.6 \%$ nitrogen were used. With this, $54 \mathrm{~kg}$ of $\mathrm{N} / \mathrm{ha}$ were added to the crop. The basic fertilization was carried out 10 days before sowing the oil pumpkins, and the additional fertilizing was done at the beginning of June in the $\mathrm{BBCH}$ $109 / 501$ growth stage. The fertilization was done on the basis of left over winter cereal straw (previous field crop) and the nutrient intake in the average Slovene yield of oil pumpkins

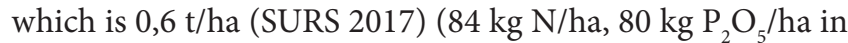
$180 \mathrm{~kg} \mathrm{~K}$ O/ha).

Considering the amount of phosphorus and potassium (Table 2) and the leftovers of the winter wheat straw $(0 \mathrm{~kg} \mathrm{~N} /$ ha, $20 \mathrm{~kg} \mathrm{P}_{2} \mathrm{O}_{5} /$ ha in $70 \mathrm{~kg} \mathrm{~K} \mathrm{O} / \mathrm{ha}$ ), nutritional needs were covered in both years in all production systems, apart from ORG in $\mathrm{BD}$ in which the average for both years resulted in $-12 \%$ and $-18 \%$ of $\mathrm{K}_{2} \mathrm{O}$ and $\mathrm{P}_{2} \mathrm{O}_{5}$, and a slight surplus of $\mathrm{K}_{2} \mathrm{O}$ in $\mathrm{CON}+26 \%$. The entire planting area was treated with a rotary harrow, after fertilization. The oil pumpkin sowing was done manually on $10^{\text {th }}$ May in both years. After the sowing, a chemical treatment against weeds was applied. For the INT production system, we applied 1.6 1/ha of Successor (petoksamid $600 \mathrm{~g} / \mathrm{l}$ ) and $0.25 \mathrm{l} / \mathrm{ha}$ of Centium (klomazon 360 $\mathrm{g} / \mathrm{l})$, and for the CON areas, we used the same chemicals in a dose of $2.0 \mathrm{l} / \mathrm{ha}$ and $0.25 \mathrm{l} / \mathrm{ha}$. The hoeing was done twice (after first emergence of plants from the ground and after the applied fertilizing) in ORG, BD and the control plots, and only once in the INT plot after applied fertilizing. Manual harvesting took place at the end of September in both years.

The same varieties were used in all farming systems in the study, namely the population variety 'Gleisdorfer Ölkürbis' and the F1 'GL Opal' hybrid. They were of conventional origin, without chemically treated seeds for ORG, BD systems and control plots.

Table 2: The average content of $\mathrm{P} 2 \mathrm{O} 5$ and $\mathrm{K} 2 \mathrm{O}$ nutrients in the soil ( $\mathrm{mg} / 100 \mathrm{~g}$ soil) in a long-term experiment at the University Agricultural Centre in 2014.

\begin{tabular}{|l|c|c|c|c|}
\hline \multirow{2}{*}{$\begin{array}{c}\text { Production } \\
\text { system }\end{array}$} & \multicolumn{2}{|c|}{$\mathbf{P}_{2} \mathbf{O}_{5}$} & \multicolumn{2}{c|}{$\mathbf{K}_{2} \mathbf{O}$} \\
\cline { 2 - 5 } & $\begin{array}{c}\text { (mg/100 } \\
\text { g soil) }\end{array}$ & $\begin{array}{c}\text { Nutrient } \\
\text { level }\end{array}$ & $\begin{array}{c}\text { (mg/100 g } \\
\text { soil })\end{array}$ & $\begin{array}{c}\text { Nutrient } \\
\text { level }\end{array}$ \\
\hline BD & 18 & $\mathrm{C}$ & 26 & $\mathrm{C}$ \\
\hline ORG & 22 & $\mathrm{C}$ & 25 & $\mathrm{C}$ \\
\hline INT & 20 & $\mathrm{C}$ & 27 & $\mathrm{C}$ \\
\hline CON & 23 & $\mathrm{C}$ & 26 & $\mathrm{C}$ \\
\hline Control & 15 & $\mathrm{C}$ & 15 & $\mathrm{~B}$ \\
\hline
\end{tabular}

$\mathrm{C}=\operatorname{good}$ (optimal) supply level of $\mathrm{P}_{2} \mathrm{O}_{5} / \mathrm{K}_{2} \mathrm{O}$ in the soil using the AL method $\mathrm{B}=$ medium supply level of $\mathrm{P}_{2} \mathrm{O}_{5} / \mathrm{K}_{2} \mathrm{O}$ in the soil using the AL method.

Table 1: Important differences in agriculture practice among the four production systems and control plots.

\begin{tabular}{|c|c|c|c|c|c|}
\hline \multicolumn{6}{|c|}{ Production system } \\
\hline & BD & ORG & INT & $\mathrm{CON}$ & Control \\
\hline Soil tillage & $\begin{array}{l}\text { Ploughing, seedbed } \\
\text { preparation, sowing, } \\
\text { hoeing, harvesting }\end{array}$ & $\begin{array}{l}\text { Ploughing, } \\
\text { seedbed } \\
\text { preparation, } \\
\text { sowing, hoeing, } \\
\text { harvesting }\end{array}$ & $\begin{array}{l}\text { Ploughing, seedbed } \\
\text { preparation, sowing, } \\
\text { hoeing, harvesting }\end{array}$ & $\begin{array}{l}\text { Ploughing, } \\
\text { seedbed } \\
\text { preparation, } \\
\text { sowing, } \\
\text { harvesting }\end{array}$ & $\begin{array}{l}\text { Ploughing, } \\
\text { seedbed } \\
\text { preparation, } \\
\text { sowing, hoeing, } \\
\text { harvesting }\end{array}$ \\
\hline $\begin{array}{l}\text { Weed } \\
\text { control }\end{array}$ & $\begin{array}{l}\text { Mechanical control of } \\
\text { weeds }\end{array}$ & $\begin{array}{l}\text { Mechanical } \\
\text { control of weeds }\end{array}$ & $\begin{array}{l}\text { Use of herbicides } \\
\text { according to the } \\
\text { Guidelines for } \\
\text { integrated field } \\
\text { crops (MKGP, 2013, } \\
\text { 2014b) Mechanical } \\
\text { control of weeds }\end{array}$ & $\begin{array}{l}\text { Preventive use of } \\
\text { herbicides }\end{array}$ & $\begin{array}{l}\text { Mechanical } \\
\text { control of weeds }\end{array}$ \\
\hline Fertilization & $\begin{array}{l}\text { Composted livestock } \\
\text { manure ( } 1.4 \mathrm{LU} / \\
\text { ha) with added BD } \\
\text { compost preparations }\end{array}$ & $\begin{array}{l}\text { Well - rotted } \\
\text { cattle manure } \\
(1.4 \mathrm{LU} / \mathrm{ha})\end{array}$ & $\begin{array}{l}\text { NPK and other } \\
\text { nitrogen mineral } \\
\text { fertilizers used } \\
\text { based on soil } \\
\text { analysis and } \\
\text { nutrient removal } \\
\text { estimates }\end{array}$ & $\begin{array}{l}\text { NPK and other } \\
\text { nitrogen mineral } \\
\text { fertilizers used } \\
\text { based on good } \\
\text { agricultural } \\
\text { practice and } \\
\text { nutrient removal } \\
\text { estimates }\end{array}$ & None \\
\hline
\end{tabular}

${ }^{\star} \mathrm{LU}-$ Livestock unit $=500 \mathrm{~kg}$ of live animal weight 


\section{Soil characteristics}

The University Agricultural Centre in Pivola has dystric cambisol (FAO 2006). Following the USDA Textural Classification System (2017), it belongs to the heavier clay texture class, whit $31 \%$ clay, $47 \%$ silt and $22 \%$ sand in $0-0.3 \mathrm{~m}$ depth. The advantage of this soil is that it provides more accessible water to the plants during extreme drought circumstances than lighter soil types.

The content of phosphorus and potassium in the soil in individual treatments was analysed using the AL method in 2014 (table 2). The soil's phosphorus and potassium supply in the $\mathrm{C}$ level was optimal, except for the potassium amount in the control production system (B level), where the plots have not been fertilized since the beginning of the long-term experiment in 2007.

The percentage of humus in the soil was between 2.2 and $2.5 \%$ and the $\mathrm{pH}$ was between 5.7 and 5.9 (in $1 \mathrm{M} \mathrm{KCl}$ ).

\section{Weather conditions}

The annual mean air temperature of the area is $10.5^{\circ} \mathrm{C}$, where the mean monthly minimum occurs in January at $-0.1{ }^{\circ} \mathrm{C}$, and the average monthly maximum is in July at $21.0^{\circ} \mathrm{C}$. The average annual rainfall in the area measured from 1981 until 2010 was $893 \mathrm{~mm}$ (ARSO 2017).

The air temperatures in spring 2013 were low, which inhibited the growth until almost mid-June, and that period was followed by a sudden transition to extreme summer conditions. After that, the area experienced three heat waves and a summer drought, which was interrupted by heat storms. Because of the occasional rainfall on the semi-heavy and heavy soil, the summer drought did not limit the growth of the plants. The oil pumpkins compensated the slow spring growth in the summer and reached their technological maturity in the middle of September (Fig. 1) (ARSO 2017).

In May 2014, there were a lot of above average intermitted warm and cold periods. The exchange of extreme heat to normal, and even under average temperatures in the first decade of June, also continued into the whole month. The consequences of the stressful circumstances affecting the growth and development of the cucurbits manifested themselves in a lower number of fruits per plant and thus exhibiting a smaller yield of oil seed pumpkins. There was an above average quantity of rainfall and rainy days during the growth period throughout Slovenia. The soil was sometimes too wet during the harvesting of the fruits and seeds in the north-east of the country, which made the ripening harder for the plants (Fig. 2) (ARSO 2017).

\section{Content of mineral nitrogen in the soil}

Mineral nitrogen (Nmin) in the soil has been sampled according to PS in both years. The sampling was carried out at sowing (BBCH 001), at the beginning of June in growth stage BBCH 109/501 (beginning growth stage of first flower initial with elongated ovary visible on main stem) and at harvesting at the end of September (BBCH 909). The growth stage determination was done by Feller et al. (1995). The two nitrogen types $\mathrm{NO}_{3}{ }^{-}$and $\mathrm{NH}_{4}^{+}$were identified by the Sharf and Wehrmann (1979) method in the chemical laboratory at the Faculty of Agriculture and Life Sciences. The sampling for identifying the mineral nitrogen content in the soil was carried out at a depth of $0-0.3$ and $0.3-0.6 \mathrm{~m}$. Six samples at both depths have been obtained per sampling in four repetitions of the experiment. In order to calculate the mineral nitrogen content, specific soil mass quantity for a specific location, which were obtained at sampling by the Kopetcky method, was used $\left(1280 \mathrm{~kg} / \mathrm{m}^{3}\right.$ and $1350 \mathrm{~kg} / \mathrm{m}^{3}$, at a soil depth from $0-0.3 \mathrm{~m}$ and $0.3-0.6 \mathrm{~m}$ ).

\section{Yield and fruit characteristics}

The harvest in both years took place when the pumpkin fruits reached their technological maturity, which means that the fruits were almost entirely yellow and had a dry stalk. The fruits of oil pumpkins were counted, weighed and

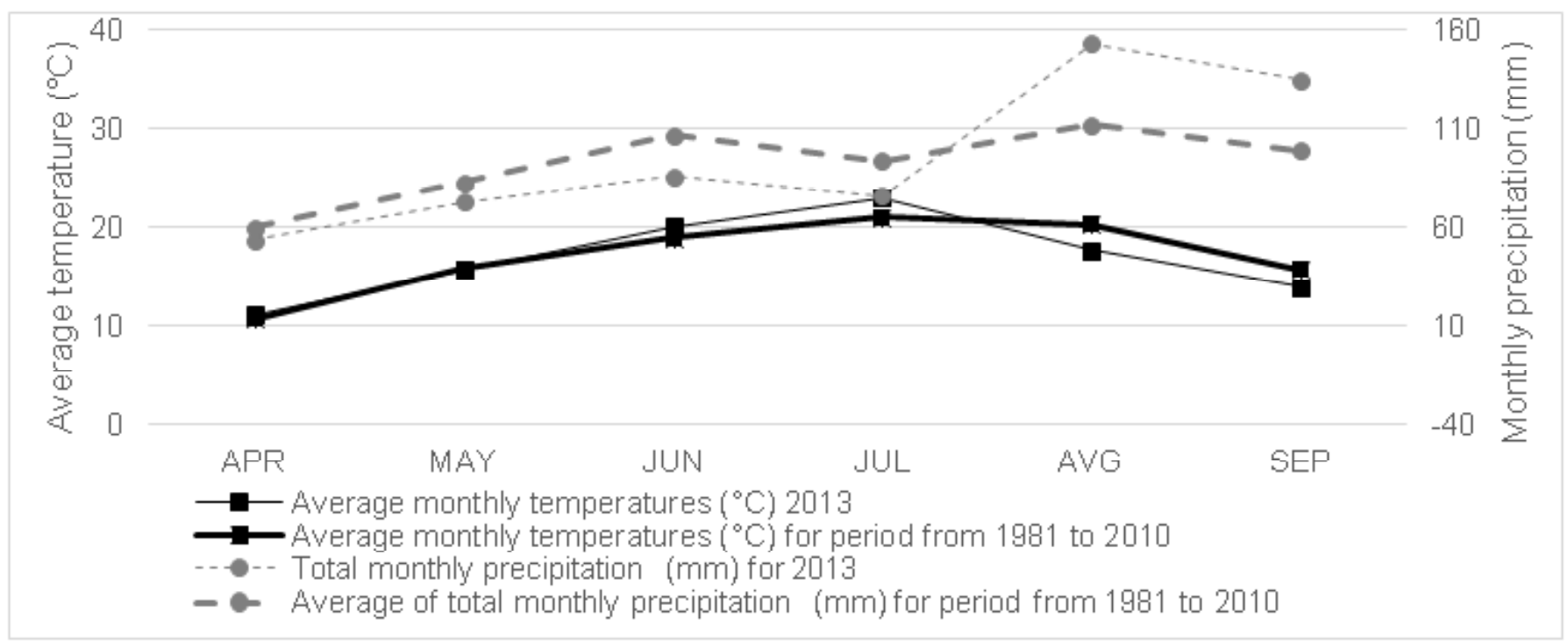

Fig. 1: Modified Walter-Gaussen climate diagram for the growing season period of pumpkins in 2013 compared to the longterm average (1981-2010) for Maribor (ARSO 2017). 


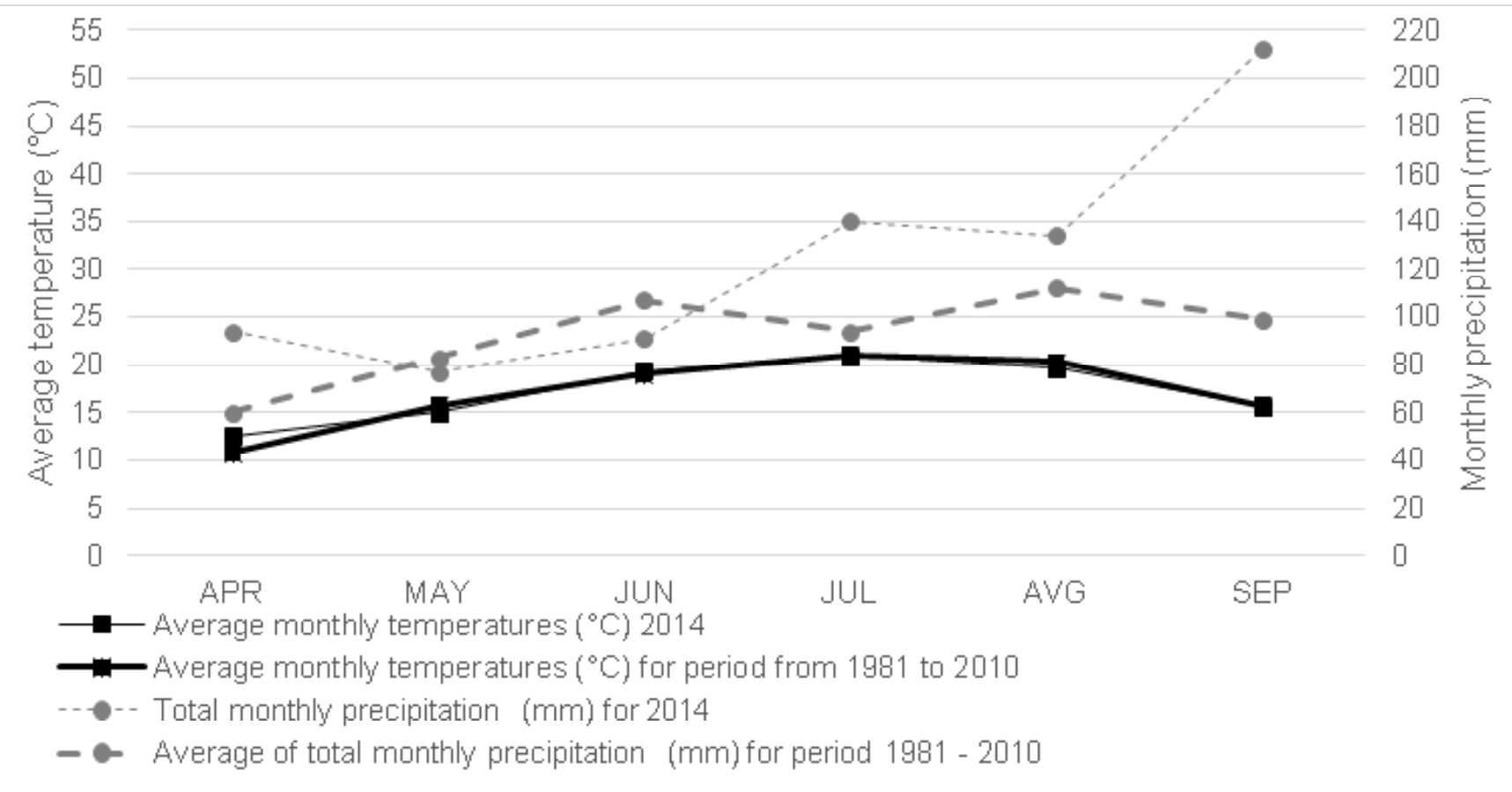

Fig. 2: Modified Walter-Gaussen climate diagram for the growing season period of pumpkins in 2014 compared to the long-term average (1981-2010) for Maribor (ARSO 2017).

put into three categories; harvestable, unripe and decayed fruits. The collected data have been calculated per ha and are thus presented in the tables. The seed yields were harvested manually and weighed for each plot. The moisture in the seeds was determined on an average sample weighing using a drying procedure for three days at $60{ }^{\circ} \mathrm{C}$. The results of the pumpkin seed harvest have been calculated at $9 \%$ moisture in the seeds.

\section{Agronomic efficiency of applied nutrients}

Agronomic efficiency of applied nutrients (AE) is one of many important defined fertilizer efficiency parameters (Good et al. 2004). It measures the efficiency of converting applied nutrients $\left(\mathrm{N}, \mathrm{P}_{2} \mathrm{O}_{5}, \mathrm{~K}_{2} \mathrm{O}\right)$ to yield of crop. However, $\mathrm{AE}$, defined as crop yield increase per kg nutrient applied and presents one of the indicators of successful agricultural production ( $\mathrm{Ma}$ at al. 2015). For calculating the agronomic efficiency for added NPK nutrients in this study, the formula used by Xu et al. (2015) has been applied;

$\mathrm{AE}\left(\mathrm{N}, \mathrm{P}_{2} \mathrm{O}_{5}\right.$ or $\left.\mathrm{K}_{2} \mathrm{O}\right)=\left(\mathrm{Y}_{\mathrm{PS}}-\mathrm{Y}_{\text {Control Plot }}\right) / \mathrm{F}\left(\right.$ Nutrients $\mathrm{N}, \mathrm{P}_{2} \mathrm{O}_{5}$ or $\left.\mathrm{K}_{2} \mathrm{O}\right)$

Where is $Y_{P S}$ is the yield of oil pumpkin seeds in a specific production system $(\mathrm{kg} / \mathrm{ha}), \mathrm{Y}_{\text {Control Plot }}$ is the yield of oil pumpkin seeds in control plots without fertilization (without adding any nutrients) $(\mathrm{kg} / \mathrm{ha})$ and $\mathrm{F}$ being $\mathrm{N}, \mathrm{P}_{2} \mathrm{O}_{5}$ or $\mathrm{K}_{2} \mathrm{O}$ representing the amount of fertilizer applied $(\mathrm{kg} / \mathrm{ha})$. This was statistically evaluated and done separately for each year and plot. The amounts of nutrients $\left(\mathrm{N}, \mathrm{P}_{2} \mathrm{O}_{5}, \mathrm{~K}_{2} \mathrm{O}\right)$ applied in 2013 and 2014 (Table 3 ) were used to calculate AE.
Table 3: The average content of $\mathrm{P}_{2} \mathrm{O}_{5}$ and $\mathrm{K}_{2} \mathrm{O}$ nutrients in the soil ( $\mathrm{mg} / 100 \mathrm{~g}$ soil) in a long-term experiment at the University Agricultural Centre in 2014.

\begin{tabular}{|l|c|c|c|c|c|c|}
\hline & \multicolumn{3}{|c|}{$\mathbf{2 0 1 3}$} & \multicolumn{3}{c|}{$\mathbf{2 0 1 4}$} \\
\hline PS & $\mathbf{N}$ & $\mathbf{P}_{2} \mathbf{O}_{5}$ & $\mathbf{K}_{2} \mathbf{O}$ & $\mathbf{N}$ & $\mathbf{P}_{2} \mathbf{O}_{5}$ & $\mathbf{K}_{2} \mathbf{O}$ \\
\hline CON & 89 & 70 & 139 & 89 & 70 & 139 \\
\hline INT & 83 & 58 & 115 & 83 & 58 & 115 \\
\hline ORG & 101 & 56 & 96 & 88 & 48 & 84 \\
\hline BD & 101 & 56 & 96 & 88 & 48 & 84 \\
\hline Control & 0 & 0 & 0 & 0 & 0 & 0 \\
\hline
\end{tabular}

PS - Production systems, $\mathrm{N}$ - nitrogen, $\mathrm{P}_{2} \mathrm{O}_{5}$ - phosphorus, $\mathrm{K}_{2} \mathrm{O}$ - potassium.

\section{Statistical methods}

Statistical analyses were performed by using the program Statgraphics Centurion (Statgraphics 2005). The impact of the investigated factors was analysed with the multifactorial analysis of variance (ANOVA). The differences between the treatments were checked using the Duncan multiple range test $(\alpha=0.05)$. The results are shown as mean values of repetition with a standard error mean $( \pm$ SEM).

\section{RESULTS AND DISCUSSION}

\section{Mineral nitrogen in the soil}

The content of Nmin in the soil $(0-0.6 \mathrm{~m})$ in all three growth stages of oil pumpkins (BBCH v 001,109/501 and 909) has been significantly influenced by the production system 
(Table 4). The year of production, along with the production system, also significantly influenced the Nmin in spring, at the beginning of May when the pumpkins started growing (BBCH 001), and at harvesting (BBCH 909). In both growth stages, the early one because of a smaller area of the root system, and the one in autumn because of a lower activity of decayed roots, nitrate nitrogen in the soil can present a source of pollution for the groundwater, due to stronger rainfalls. The PS $(\mathrm{P} \leq 0.001)$ has a significant impact on the amount of mineral nitrogen in the zone of the oil pumpkin roots, in the BBCH 109/501 growth stages. In May, at the beginning of the pumpkin growth period $(\mathrm{BBCH} 001)$, the amount of Nmin in ORG production $(59.6 \mathrm{~kg} / \mathrm{ha}$ ) was significantly higher when compared to the other PS, except for CON (51.1 $\mathrm{kg} / \mathrm{ha}$ ). At the beginning of June, the distinctively highest content of Nmin in the soil was in BD and the control plots ( 106.7 in $98.3 \mathrm{~kg} / \mathrm{ha}$, respectively) when compared to the other production systems. After the harvest, the remaining Nmin in the soil was significantly higher on the BD and ORG plots in comparison with the CON and control plots. INT only significantly differed from BD.

Table 4: Mineral nitrogen content in soil $(0-0.6 \mathrm{~m})$ in different production systems.

\begin{tabular}{|l|c|c|c|}
\hline & \multicolumn{3}{|c|}{ Nmin (0- 0.6 m) kg/ha } \\
\hline Factor & BBCH 001 & $\begin{array}{c}\text { BBCH } \\
109 / 501\end{array}$ & BBCH 909 \\
\hline $\begin{array}{l}\text { Production } \\
\text { system (PS) }\end{array}$ & $* *$ & $* * *$ & $* *$ \\
\hline Year (Y) & $* * *$ & NS & $* * *$ \\
\hline Interaction & & & \\
\hline PS $\times$ Y & $\star *$ & NS & NS \\
\hline $\begin{array}{l}\text { Production } \\
\text { system }\end{array}$ & & & \\
\hline BD & $49.3 \pm 6.5^{\mathrm{bc}}$ & $106.7 \pm 7.1^{\mathrm{a}}$ & $107.0 \pm 22.0^{\mathrm{a}}$ \\
\hline ORG & $59.6 \pm 5.5^{\mathrm{a}}$ & $63.2 \pm 9.2^{\mathrm{b}}$ & $95.2 \pm 12.4^{\mathrm{ab}}$ \\
\hline INT & $44.4 \pm 3.5^{\mathrm{bc}}$ & $62.0 \pm 7.9^{\mathrm{b}}$ & $86.0 \pm 18.2^{\mathrm{bc}}$ \\
\hline CON & $51.1 \pm 7.8^{\mathrm{ab}}$ & $65.5 \pm 7.8^{\mathrm{b}}$ & $73.2 \pm 16.2^{\mathrm{c}}$ \\
\hline Control & $40.1 \pm 2.5^{\mathrm{c}}$ & $98.3 \pm 6.3^{\mathrm{a}}$ & $73.3 \pm 14.4^{\mathrm{c}}$ \\
\hline Year & & & \\
\hline 2013 & $38.2 \pm 2.4^{\mathrm{b}}$ & $75.0 \pm 7.7$ & $45.7 \pm 3.2^{\mathrm{b}}$ \\
\hline 2014 & $59.5 \pm 3.0^{\mathrm{a}}$ & $83.3 \pm 4.7$ & $128.2 \pm 6.4^{\mathrm{a}}$ \\
\hline
\end{tabular}

${ }^{* *},{ }^{* *}$ significant at the 0.01 and 0.001 probability levels, respectively; NS non significant; a-c mean values $( \pm$ SEM) followed by different letters within a column and particular factor are significantly different (Duncan, $\alpha=0.05$ ).

The Guidelines for integrated vegetable production (MKGP 2014c) state that the recommended residual of Nmin in the soil $(0-0.6 \mathrm{~m})$ after an oil pumpkin harvest needs to be less than $80 \mathrm{~kg} / \mathrm{ha}$. The Nmin in the soil was generally higher in BD and ORG treatments, where we added composted or mature stable manure each year before sowing. Fertilisation in those treatments was also combined with double hoeing performed after the emergence of the plants and after additional fertilising with $\mathrm{N}$ in June. The yearly addition of organic fertilizer during optimum conditions for mineralization and suitable agricultural practices, also ensure the intensive nitrogen mineralization in autumn when the plants' need for nutrients is lower. Our results are the same as those of Bavec et al. (2015), which state that higher hoeing frequencies in sweet corn tillage sped up the process of mineralization and thus significantly increased the amount of Nmin in the soil in June, and after harvest, when compared with their control plot (Nmin values in soil). The higher Nmin quantities in the soil also significantly influenced the higher yield of sweet corn. Becker and Boehrnsen (1994) also state that hoeing speeds up the processes of transforming organic nitrogen into mineral forms. Mechanical treatment of soil influences oxidation processes in the soil and enable a better and faster access to nutrients, while improving the physical, chemical and biological conditions in the soil, especially in organic farming systems (Silgram and Shepherd 1999, Bavec and Bavec 2007). The significantly higher amounts of Nmin in the soil at the beginning of May 2014 when compared to 2013, are a result of higher air temperatures in spring, resulting in higher temperatures of the upper soil layer, which influenced a higher mineralization in the soil. De Neve and Hofman (2000) state that when supplying soil with a sufficient amount of moisture, higher temperatures significantly influence the mineralization in the soil, making it stronger and faster. After storing the harvest in 2014, the left over amounts of mineral nitrogen were significantly higher, almost three times higher, when compared to the previous year. High amounts of Nmin can also be a consequence of residual Nmin in the soil because of poor oil pumpkin growth in the summer months of 2014, resulting in a lower fruit and pumpkin seed yield.

\section{Yield of oil seed pumpkin and fruits characteristics}

Production system, variety and year had a significant impact on the number of all fruits and the number of harvested fruits (Table 5). The significantly highest number of all fruits and number of harvested fruits per hectare were in the INT (16071, 15479 respectively) production system. The number of all fruits and harvested fruits were not significantly different in BD and ORG. BD and INT were the only ones among the production system treatments, which had an above average relative number of harvested fruits in the experiment (116\% in 101\%). Interactions among years, production systems and varieties for analysed factors were not significantly different. A significantly higher number of all fruits and number of harvested fruits are found in the hybrid variety when compared to the population variety (for $11 \%$ and $10 \%)$ and in 2013 when compared to 2014 (29\% in 30\%). A smaller number of fruits in 2014 was due to the exchange of high and low temperatures during the flowering of the pumpkins in June. Wien (1997) states that in the Cucurbita pepo L. species, cold weather causes the male flowers to open a few days later than the female ones, which causes a decreased fertility and thus a lower number of fruits at harvest. For successful fertilization, simultaneous blooming of male and female flowers is of importance (Ivančič 2002).

The production system and year had a significant impact on the harvest fruit weight. On average, the production system and variety had a significant impact on the weight of the harvested fruits. Interaction was significant in case of PS and year $(\mathrm{PS} \times \mathrm{Y})($ Table 6$)$. In the control plot and $\mathrm{CON}$, the weight harvest fruits were significantly lower when compared 
Table 5: The effect of treatments on number of all, harvested, unripe decayed oil pumpkin fruits and relative number of harvested fruits.

\begin{tabular}{|c|c|c|c|c|c|}
\hline & $\begin{array}{l}\text { Number of all } \\
\text { fruits (ha) }\end{array}$ & $\begin{array}{c}\text { Number of } \\
\text { harvested fruits (ha) }\end{array}$ & $\begin{array}{l}\text { Relative number of } \\
\text { harvested fruits (\%) }\end{array}$ & $\begin{array}{l}\text { Number of unripe } \\
\text { fruits (ha) }\end{array}$ & $\begin{array}{c}\text { Number of } \\
\text { decayed fruits } \\
\text { (ha) }\end{array}$ \\
\hline $\begin{array}{l}\text { Production } \\
\text { system (PS) }\end{array}$ & $* * *$ & $* * *$ & I & NS & NS \\
\hline Variety (V) & $* *$ & $* *$ & I & NS & NS \\
\hline Year $(\mathrm{Y})$ & $* * *$ & $* * *$ & I & NS & NS \\
\hline \multicolumn{6}{|l|}{ Interaction } \\
\hline $\mathrm{PS} \times \mathrm{V}$ & NS & NS & 1 & NS & NS \\
\hline $\mathrm{PS} \times \mathrm{Y}$ & NS & NS & I & NS & NS \\
\hline $\mathrm{Y} \times \mathrm{V}$ & NS & NS & I & NS & NS \\
\hline $\mathrm{PS} \times \mathrm{V} \times \mathrm{Y}$ & NS & NS & I & NS & NS \\
\hline \multicolumn{6}{|l|}{$\begin{array}{l}\text { Production } \\
\text { system (PS) }\end{array}$} \\
\hline $\mathrm{BD}$ & $13992 \pm 815^{\mathrm{b}}$ & $13455 \pm 791^{\mathrm{b}}$ & 101 & $382 \pm 90$ & $156 \pm 68$ \\
\hline ORG & $13959 \pm 650^{\mathrm{b}}$ & $13232 \pm 608^{\mathrm{bc}}$ & 99 & $486 \pm 122$ & $242 \pm 78$ \\
\hline INT & $16071 \pm 845^{\mathrm{a}}$ & $15479 \pm 806^{\mathrm{a}}$ & 116 & $504 \pm 130$ & $88 \pm 40$ \\
\hline $\mathrm{CON}$ & $13259 \pm 571^{b}$ & $12547 \pm 623^{\mathrm{bc}}$ & 94 & $393 \pm 100$ & $319 \pm 90$ \\
\hline Control & $12653 \pm 638^{b}$ & $11835 \pm 569^{c}$ & 89 & $571 \pm 159$ & $246 \pm 81$ \\
\hline \multicolumn{6}{|l|}{ Variety } \\
\hline PV & $13283 \pm 470^{\mathrm{b}}$ & $12707 \pm 484^{\mathrm{b}}$ & 95 & $428 \pm 65$ & $148 \pm 43$ \\
\hline $\mathrm{HY}$ & $14690 \pm 460^{a}$ & $13910 \pm 432^{\mathrm{a}}$ & 105 & $506 \pm 87$ & $272 \pm 49$ \\
\hline \multicolumn{6}{|l|}{ Year } \\
\hline 2013 & $15744 \pm 491^{\mathrm{a}}$ & $15031 \pm 444^{\mathrm{a}}$ & 113 & $552 \pm 96$ & $161 \pm 44$ \\
\hline 2014 & $12230 \pm 294^{b}$ & $11588 \pm 301^{b}$ & 87 & $383 \pm 48$ & $259 \pm 50$ \\
\hline Average & 13987 & 13310 & 100 & 467 & 211 \\
\hline
\end{tabular}

**, ${ }^{* *}$ significant at the 0.01 and 0.001 probability levels, respectively; NS - non significant; a-c mean values $( \pm$ SEM) followed by different letters within a column and particular factor are significantly different (Duncan, $\alpha=0.05$ ).

Table 6: The effect of treatments on weight of harvest, unripe pumpkin fruits, average fruit weight of harvest and relative weight of harvested fruits.

\begin{tabular}{|c|c|c|c|c|c|}
\hline & $\begin{array}{l}\text { Number of all } \\
\text { fruits (ha) }\end{array}$ & $\begin{array}{c}\text { Number of } \\
\text { harvested fruits } \\
\text { (ha) }\end{array}$ & $\begin{array}{c}\text { Relative number } \\
\text { of harvested } \\
\text { fruits (\%) }\end{array}$ & $\begin{array}{l}\text { Number of } \\
\text { unripe fruits } \\
\text { (ha) }\end{array}$ & $\begin{array}{c}\text { Number of } \\
\text { decayed fruits } \\
\text { (ha) }\end{array}$ \\
\hline $\begin{array}{l}\text { Production system } \\
\text { (PS) }\end{array}$ & $* * *$ & $* * *$ & I & NS & NS \\
\hline Variety (V) & $* *$ & $* *$ & I & NS & NS \\
\hline Year $(Y)$ & $* * *$ & $* * *$ & 1 & NS & NS \\
\hline \multicolumn{6}{|l|}{ Interaction } \\
\hline $\mathrm{PS} \times \mathrm{V}$ & NS & NS & 1 & NS & NS \\
\hline $\mathrm{PS} \times \mathrm{Y}$ & NS & NS & 1 & NS & NS \\
\hline $\mathrm{Y} \times \mathrm{V}$ & NS & NS & 1 & NS & NS \\
\hline $\mathrm{PS} \times \mathrm{V} \times \mathrm{Y}$ & NS & NS & I & NS & NS \\
\hline \multicolumn{6}{|l|}{$\begin{array}{l}\text { Production system } \\
\text { (PS) }\end{array}$} \\
\hline $\mathrm{BD}$ & $13992 \pm 815^{b}$ & $13455 \pm 791^{\mathrm{b}}$ & 101 & $382 \pm 90$ & $156 \pm 68$ \\
\hline ORG & $13959 \pm 650^{b}$ & $13232 \pm 608^{\mathrm{bc}}$ & 99 & $486 \pm 122$ & $242 \pm 78$ \\
\hline INT & $16071 \pm 845^{\mathrm{a}}$ & $15479 \pm 806^{\mathrm{a}}$ & 116 & $504 \pm 130$ & $88 \pm 40$ \\
\hline $\mathrm{CON}$ & $13259 \pm 571^{\mathrm{b}}$ & $12547 \pm 623^{\mathrm{bc}}$ & 94 & $393 \pm 100$ & $319 \pm 90$ \\
\hline Control & $12653 \pm 638^{b}$ & $11835 \pm 569^{c}$ & 89 & $571 \pm 159$ & $246 \pm 81$ \\
\hline \multicolumn{6}{|l|}{ Variety } \\
\hline $\mathrm{PV}$ & $13283 \pm 470^{\mathrm{b}}$ & $12707 \pm 484^{\mathrm{b}}$ & 95 & $428 \pm 65$ & $148 \pm 43$ \\
\hline $\mathrm{HY}$ & $14690 \pm 460^{\mathrm{a}}$ & $13910 \pm 432^{\mathrm{a}}$ & 105 & $506 \pm 87$ & $272 \pm 49$ \\
\hline \multicolumn{6}{|l|}{ Year } \\
\hline 2013 & $15744 \pm 491^{\mathrm{a}}$ & $15031 \pm 444^{\mathrm{a}}$ & 113 & $552 \pm 96$ & $161 \pm 44$ \\
\hline 2014 & $12230 \pm 294^{b}$ & $11588 \pm 301^{\mathrm{b}}$ & 87 & $383 \pm 48$ & $259 \pm 50$ \\
\hline Average & 13987 & 13310 & 100 & 467 & 211 \\
\hline
\end{tabular}

${ }^{* *},{ }^{* * *}$ significant at the 0.01 and 0.001 probability levels, respectively; NS - non significant; a-c mean values $( \pm$ SEM) followed by different letters within a column and particular factor are significantly different (Duncan, $\alpha=0.05$ ). 
to INT and $\mathrm{BD}$, but $\mathrm{BD}$ and $\mathrm{CON}$ not being significantly different. The same holds true for the average weight of harvested fruits, with the difference of $\mathrm{BD}$ and CON being significantly different. In 2013, the harvest fruit weight was significantly higher by a third, in comparison to 2014 .

Although the average weight of a mature fruit in the population variety is significantly higher by $14 \%$ when compared to the hybrid, other fruit characteristics such as number of harvested fruits (Table 5) and higher percentage of seed harvest (Table 7) have influenced the final significantly higher yield of the hybrid variety per hectare (Table 7). The seed yield of pumpkins (given at $9 \%$ moisture in seed) and the average seed weight per fruit, varied among PS, varieties and years (Table 7). The interaction between the studied factors is not statistically significant in any of the observed characteristics. The INT production system had a significantly higher pumpkin seed yield (922 kg/ha) and a higher average weight of pumpkin seed per fruit (57.6 g) when compared to all the other production systems apart from BD $(804 \mathrm{~kg} / \mathrm{ha}$, $57.1 \mathrm{~g})$. The lowest pumpkin seed yield occurred on CON and control plots ( $666 \mathrm{~kg} / \mathrm{ha}$ in $630 \mathrm{~kg} / \mathrm{ha})$. The average seed yield in 2013 and 2014 in our study was a third higher on average than the average across Slovenia (SURS 2017). Turinek (2011) also conducted a three-year long-term study with the same design and did not find any significant influence of production system and year of production on the pumpkin seed yield, whereas we found a significant influence of those factors on the seed yield. Regardless of this, the comparison between the value and the relative yield of pumpkin seeds (in \%) in the production systems in both experiments show comparable results. Both studies show that the seed yield in INT and BD are above the average of the whole experiment (2009-2011; 124\%, 107\%, 2013-2014; 123\%, 108\%). A significant influence of the PS and the growth of the yield in both organic PS, are the result of several years of good farming practices carried out in those plots. Martini et al. (2004) and Seufert et al. (2012) state in their research, that soil fertility in organic farming establishes itself after three or more years of applying an organic farming practice, when compared to conventional farming practices. CON, ORG and the control plots had a significantly lower average weight of pumpkin seeds than INT. The higher average weight of the pumpkin fruits $(\mathrm{kg})$ (Table 6), trend of higher number and weight of harvest fruits (Table 5 and 6) and average weight of seeds/fruit (Table 7) in $\mathrm{BD}$, when compared to ORG, can be explained through the significantly higher amount of available Nmin in the soil during the BBCH 109/501 growth stage (Table 4). Bavec and Bavec (2007) claim that in oil pumpkins, during the BBCH 501 stage, the supply of nitrogen significantly influences the amount of pumpkin seed yield. The significantly higher or equal yield of seed/ha and seed/fruit in $\mathrm{BD}$ and ORG when compared to CON, are the result of adequate supply of organic production systems with organic fertilizers. Providing oxidizing conditions in the soil using the appropriate mechanical measures, which are essential for the mineralization of nutrients from stable manure during crop growth from May to Avgust, ensures a comparable or even better supply of mineral nitrogen in organic than in conventional systems. Seuferta et al. (2012) state that nitrogen is mostly a limiting factor for yield formation in organic production systems. In organic production systems, where there is enough available nitrogen in the soil for creating the necessary conditions for a fertile soil, the yield is not lower than in conventional systems.

When comparing the productivity of the new hybrid ('GL Opal') and the older population variety ('Gleisdorfer Ölkürbis'), a significantly higher yield is observed in the hybrid variety $(21 \%)$. In comparison with the whole experiment, it is $11 \%$ higher. The average weight of pumpkin seeds per fruit $(55.4 \mathrm{~g})$ is also significantly higher in the hybrid when compared with the population variety. Most new varieties have increased their resistance to illnesses and pests and improved their use of nutrients in the soil, which has been achieved by using improved methods of plant breeding, which significantly influences the yield formation (Rochester and Constable 2015). The weather conditions in both years influenced the pumpkin seed yield equally significantly $(\mathrm{P} \leq$ 0.001) than the other included factors (PS, V). Unfavourable conditions for the growth and development of the pumpkins in 2014 have been the above average amount of rainfall in the summer, and many temperature fluctuations in May and June (Figure 2) which alternated in a few day intervals during the days and nights. The unfavourable growth conditions have also significantly influenced the lower average weight of pumpkin seeds per fruit (50.2 g), when compared to the more favourable 2013 (55.1 g). The oil pumpkin is a very low temperature sensitive plant when in its initial growth stage (Bavec and Bavec 2007) and it is also sensitive to temperature fluctuations which negatively impacts the blooming timing of the female and male flowers and thus the number of pumpkins and their seed yield (Wien 1997, Ivančič 2002).

\section{Agronomic efficiency}

The AE of the nutrients added in the form of mineral or organic $\mathrm{N}, \mathrm{P}_{2} \mathrm{O}_{5}$, and $\mathrm{K}_{2} \mathrm{O}$ (depending on the individual PS) differ significantly among PS, and in $\mathrm{P}_{2} \mathrm{O}_{5}$ and $\mathrm{K}_{2} \mathrm{O}$ among varieties (Table 8). The year did not have a significant influence on $\mathrm{AE}$ in any of the studied nutrients. Based on the analysis of the results, it can be concluded that all three nutrients have a better AE in using $\mathrm{N}$ in INT, and a better usage of $\mathrm{P}$ and $\mathrm{K}$ in INT and BD when compared to CON. Organic production systems of oil pumpkins are in the middle between $\mathrm{BD}$ and CON when it comes to AE. Turinek (2011) showed in the first years of his long-term experiment in the same location, that he received a higher AE of nutrients in oil pumpkins in different PS when compared to our results. The trends among the PS are the same, although the differences among the PS were not significant in 2008, 2009 and 2010. The results show that along with fertilizing and adding nutrients, agrotechnical measures of aerating and loosening the soil during vegetation are necessary in order to ensure conditions that are beneficial for the growth and development of the roots. That enables $\mathrm{AE}$, which is shown in the presented study in INT, BD and ORG production systems. AE is influenced by a lot of factors, such as nutrient content in the soil of control and other plots, types and amounts of fertilizers, agrotechnical measures and climate conditions (Chuan et al. 2013). Nitrogen and phosphorus have the highest average AE amount among the nutrients, where the pumpkin yield increases by $2 \mathrm{~kg}$ per 1 
Table 7: The effects of treatments on yield of oil pumpkin seeds with $9 \%$ of moisture $(\mathrm{kg} / \mathrm{ha})$ and average weight of seeds/ harvested fruits $(\mathrm{g})$.

\begin{tabular}{|c|c|c|c|}
\hline & $\begin{array}{l}\text { Seed yield of pumpkins } \\
\text { with } 9 \% \text { moisture (kg/ha) }\end{array}$ & Relative seed yield (\%) & $\begin{array}{c}\text { Average weight of seeds/harvested } \\
\text { fruits (g) }\end{array}$ \\
\hline Production system (PS) & $* * *$ & & * \\
\hline Variety $(\mathrm{V})$ & $* * *$ & & * \\
\hline Year $(\mathrm{Y})$ & $* * *$ & & * \\
\hline \multicolumn{4}{|l|}{ Interaction } \\
\hline $\mathrm{PS} \times \mathrm{V}$ & NS & & NS \\
\hline $\mathrm{PS} \times \mathrm{Y}$ & NS & & NS \\
\hline $\mathrm{Y} \times \mathrm{V}$ & NS & & NS \\
\hline $\mathrm{PS} \times \mathrm{V} \times \mathrm{Y}$ & NS & & NS \\
\hline \multicolumn{4}{|l|}{ Production system (PS) } \\
\hline $\mathrm{BD}$ & $804 \pm 73^{\mathrm{ab}}$ & 108 & $57.1 \pm 3.2^{\mathrm{ab}}$ \\
\hline ORG & $716 \pm 74^{\mathrm{bc}}$ & 96 & $49.1 \pm 3.5^{\mathrm{b}}$ \\
\hline INT & $922 \pm 64^{\mathrm{a}}$ & 123 & $57.6 \pm 2.5^{\mathrm{a}}$ \\
\hline $\mathrm{CON}$ & $666 \pm 51^{\mathrm{c}}$ & 89 & $49.5 \pm 2.2^{\mathrm{b}}$ \\
\hline Control & $630 \pm 56^{c}$ & 84 & $49.5 \pm 2.8^{\mathrm{b}}$ \\
\hline \multicolumn{4}{|l|}{ Variety } \\
\hline $\mathrm{PV}$ & $669 \pm 37^{\mathrm{b}}$ & 90 & $49.9 \pm 1.9^{\mathrm{b}}$ \\
\hline $\mathrm{HY}$ & $826 \pm 45^{\mathrm{a}}$ & 111 & $55.4 \pm 1.8^{\mathrm{a}}$ \\
\hline \multicolumn{4}{|l|}{ Year } \\
\hline 2013 & $882 \pm 49^{a}$ & 118 & $55.1 \pm 2.3^{\mathrm{a}}$ \\
\hline 2014 & $613 \pm 20^{\mathrm{b}}$ & 82 & $50.2 \pm 1.2^{\mathrm{b}}$ \\
\hline Average & 747 & 100 & 52.6 \\
\hline
\end{tabular}

${ }^{*},{ }^{* *}$ significant at the 0.05 and 0.001 probability levels, respectively; NS - non significant; a-c mean values $( \pm$ SEM) followed by different letters within a column and particular factor are significantly different (Duncan, $\alpha=0.05$ ).

$\mathrm{kg}$ of added $\mathrm{N}$ or $\mathrm{P}_{2} \mathrm{O}_{5} \mathrm{~K}_{2} \mathrm{O}$ is about half less effective. The two to five times lower $\mathrm{AE}$ of nutrients in our experiment, when compared to other studies conducted on oil pumpkins and studies conducted on other plants (Turinek 2011, Chuan et al. 2013, Fixen et al. 2015, Ren et al. 2015), is probably due to the supply of particular nutrients in the soil of the control plot. The control plot is relatively well supplied with phosphorus, potassium (Table 2) and mineral nitrogen (Table 3) throughout the entire vegetation growth period of the oil pumpkins. The high amounts of Nmin in the soil are due to the good mineralization of plant residue, which stays on the soil after harvesting.

When analysing the effects of variety on the usage of macro nutrients in oil pumpkins, the results show higher amounts of $\mathrm{AE}$ in $\mathrm{P}_{2} \mathrm{O}_{5}$ and $\mathrm{K}_{2} \mathrm{O}$ in hybrid when compared to population variety. There are no differences among the varieties when it comes to nitrogen utilization, although one would expect that due to plant breeding, the new varieties would be more efficient in utilizing the nitrogen. Our results are similar to those obtained by Rochester and Constable (2015), who found that newer population varieties and hybrids can be expected to have a better micro and macro nutrient utilization, which results in better quality and quantity of the yield. In the future, plant breeding will be even more focused on improving the utilization of all nutrients.
Table 8: Agronomic efficiency of added N, P2O2 and K2O nutrients depending on production system, variety and year.

\begin{tabular}{|c|c|c|c|}
\hline & $\operatorname{AE}(\mathbf{N})$ & $\operatorname{AE}\left(\mathrm{P}_{2} \mathrm{O}_{5}\right)$ & $\mathrm{AE}\left(\mathrm{K}_{2} \mathrm{O}\right)$ \\
\hline $\begin{array}{l}\text { Production } \\
\text { system (PS) }\end{array}$ & $* * *$ & $*$ & * \\
\hline Variety (V) & NS & * & * \\
\hline Year (Y) & NS & NS & NS \\
\hline \multicolumn{4}{|l|}{ Interaction } \\
\hline $\mathrm{PS} \times \mathrm{V}$ & $* *$ & $* * *$ & $* * *$ \\
\hline $\mathrm{PS} \times \mathrm{Y}$ & NS & NS & NS \\
\hline $\mathrm{Y} \times \mathrm{V}$ & NS & NS & NS \\
\hline $\mathrm{PS} \times \mathrm{V} \times \mathrm{Y}$ & NS & NS & NS \\
\hline \multicolumn{4}{|l|}{$\begin{array}{l}\text { Production } \\
\text { system (PS) }\end{array}$} \\
\hline $\mathrm{BD}$ & $1.8^{\mathrm{b}}$ & $2.7^{\mathrm{ab}}$ & $1.6^{\mathrm{a}}$ \\
\hline ORG & $0.9^{\mathrm{bc}}$ & $0.7^{\mathrm{bc}}$ & $0.4^{\mathrm{ab}}$ \\
\hline INT & $3.5^{\mathrm{a}}$ & $3.2^{\mathrm{a}}$ & $1.6^{\mathrm{a}}$ \\
\hline $\mathrm{CON}$ & $0.4^{\mathrm{c}}$ & $0.3^{c}$ & $0.2^{\mathrm{b}}$ \\
\hline Control & $0.0^{c}$ & $0.0^{c}$ & $0.0^{\mathrm{b}}$ \\
\hline \multicolumn{4}{|l|}{ Variety } \\
\hline PV & 1.2 & $0.4^{\mathrm{b}}$ & $0.2^{\mathrm{b}}$ \\
\hline HY & 1.4 & $2.3^{\mathrm{a}}$ & $1.2^{\mathrm{a}}$ \\
\hline \multicolumn{4}{|l|}{ Year } \\
\hline 2013 & 1.5 & 2.0 & 1.1 \\
\hline 2014 & 1.2 & 0.7 & 0.4 \\
\hline
\end{tabular}

${ }^{*}, * *, * * *$ significant at the $0.05,0.01$ and 0.001 probability levels, respectively; NS - non significant; a-c mean values ( \pm SEM) followed by different letters within a column and particular factor are significantly different (Duncan, $\alpha=0.05)$. 


\section{CONCLUSIONS}

The article presents the results of producing oil pumpkins in the seventh and eighth year of a long-term field trial with four different production systems at the University Agricultural Centre Pohorski Dvor of the University of Maribor. We can conclude that the BD (biodynamic) and ORG (organic) production systems result in higher soil Nmin contents, because of a more efficient mineralisation than in CON (conventional) and INT (integrated) production systems. The AE response of oil pumpkins, considering the amount of added nutrients in biodynamic and organic production systems, is better or equal when compared to a conventional production system. Similarly, that also holds true for the hybrid variety. By using an appropriate system in all cultivation treatments, we can expect equal or significantly higher parameters of fruit characteristics and higher seed yields in ORG and BD production systems when compared to the other production systems (INT, CON). The use of the hybrid instead of the population variety can increase the yield significantly and express a more stable yield even in years when the soil and climate conditions are less favourable.

\section{ACKNOWLEDGMENT}

The authors acknowledge that the project Alternative field crops under different production systems, crop rotations as a basic principal for adaptation to climate changes and qualitative feed-food supply (CRP, V4-1137), was financially supported by the Slovenian Research Agency.

\section{REFERENCES}

1. Bavec F. Navadna, oljna buča (Cucurbita pepo L. convar. citrullina (L.) Greb. var. styriaca Greb.) In: Nekatere zapostavljene in/ali nove poljščine. Fakulteta za kmetijstvo, Maribor, 2000.

2. Bavec F, Bavec M. Organic production and use of alternative crops. CRC/Taylor \& Francis, Boca Raton, New York, London 2007.

3. Bavec M, Bavec F, Jakop M, Mlakar SG, Fekonja M. Productivity of sweet maize (Zea mays L. Saccharata) and nitrogen supply affected by cultivation systems in nontypical maize climate. Bulg. J. Agric. Sci. 2015;21:791800.

4. Bavec F, Jakop M. Pridelovanje buč golic. Kmetovalec. 1994;5:6-7.

5. Bavec F, Jakop M, Grobelnik Mlakar S, Robačer M, Bavec M. Alternative field crops under different production systems, crop rotations as a basic principal for adaptation to climate changes and quality feed - food supply. Finale report CRP 2011-2014 V4-1137. University of Maribor, Faculty of Agriculture and Life Sciences. 2014;88.

6. Bavec M, Mlakar SG, Rozman C, Pazek K, Bavec F. Sustainable agriculture based on integrated and organic guidelines: understanding terms - the case of Slovenian development and strategy. Outlook Agric. 2009;38:8995.
7. Becker K. Boehrnsen A. Effects of mechanical treatments on weed abundance and $\mathrm{N}$-mineralization in the soil. Zeitschrift für Pflanzenkrankheiten und Pflanzenschutz. Sonderheft,1994. http://agris.fao.org/agrissearch/search. do?recordID=DE94U0282 (15.6.2017).

8. Berry PM, Sylvester-Bradley R, Philipps L, Hatch DJ, Cuttle SP, Rayns FW, Gosling P. Is the productivity of organic farms restricted by the supply of available nitrogen. Soil Use Manag. 2002;18:248-255.

9. Chuan L, Hea P, Pampolinoc MF, Johnstond AM, Jin J, Xua X, Zhaoa S, Qiua S, Zhoua W. Establishing a scientific basis for fertilizer recommendations for wheat in China: Yield response and agronomic efficiency. Field Crop Res. 2013;140:1-8.

10. Commission Regulation (EC) No. 889/2008 of 5 September 2008 laying down detailed rules for the implementation of Council Regulation (EC) No 834/2007 on organic production and labelling of organic products with regard to organic production, labelling and control. Official Journal of the European Union. 2008;L 250:184.

11. Connor DJ. Organic agriculture cannot feed the world. Field Crops Res. 2008;106(2):187-190.

12. Council Regulation (EC) No. 834/2007 of 28 June 2007 on organic production and labeling of organic products and repealing, Regulation (EEC) No. 2092/91. Official Journal of the European Union. 2007;L 189:1-23.

13. De Neve S, Hofman G. Influence of soil compaction on alone explained a very large portion of the variance: $\mathrm{C}$ and $\mathrm{N}$ mineralization from soil organic matter and crop residues. Biol. Fertil. Soils 2000;30:544-549.

14. de Ponti T, Rijk B, van Ittersum MK. The crop yield gap between organic and conventional agriculture. Agr. Syst. 2012;108:1-9.

15. Deikea S, Palluttb B, Christena O. Investigations on the energy efficiency of organic and integrated farming with specific emphasis on pesticide use intensity. Eur. J. Agron. 2008;28(3):461-470.

16. Demeter International e.V. 2012. Production Standards for the use of Demeter, Biodynamic and related trademarks. http://www.demeter.net/certification/ standards/ production (09.03.2013).

17. FAO. World Reference Base for Soil Resources. ISSSISRIC-FAO, Rome. Report No. 103, 2006.

18. Feller C, Bleiholder H, Buhr L, Hack H, Hess M, Klose R, Meier U, Stauss R, Boom T, Weber E. Phänologische Entwicklungsstadien von Gemüsepflanzen: II. Fruchtgemüse und Hülsenfrüchte. Pflanzenschutzd 1995;47: 217-232.

19. Fixen P, Brentrup F, Bruulsema T, Garcia F, Norton R, Zingore S. Nutrient/Fertilizer Use Efficiency: Measurement, Current Situation and Trends. In: Drechsel P, Heffer P, Magen H, Mikkelsen R, Wichelns D (eds.), Managing Water and Fertilizer for Sustainable Agricultural Intensification. International Fertilizer Industry Association (IFA), International Water Management Institute (IWMI), International Plant Nutrition Institute (IPNI), and International Potash Institute (IPI). 1st edition, Paris, 2015.

20. Goetzke B, Nitzko S, Spiller A. Consumption of organic 
and functional food. A matter of well-being and health. Appetite. 2014;77(1):96-105.

21. Good AG, Shrawat AK, Muench DG. Can less yield more? Is reducing nutrient input into the environment compatible with maintaining crop production? Trends Plant Sci. 2004;9(12):597-605.

22. Ivančič A. Osnove rastlinske hibritizacije. Maribor, Fakulteta za kmetijstvo 2002; 88-122.

23. Jakop M. The effects of cover crops, cultivation system and location on soil mineral nitrogen, growth and yield organically produced oil pumpkins (Cucurbita pepo L. convar. citrullina (L.) Greb. var. styriaca Greb.) [M. Sc. Thesis]. Maribor: Faculty of Agriculture and Life Sciences, University of Maribor 2010.

24. Jariene E, Danilcenko H, Kulaitiene J, Gajewski M. Effect of fertilizers on oil pumpkin seeds crude fat, fibre and protein quantity. Agron. Res. 2007;5(1):43-49.

25. Kocjan Ačko D. Buča. In: Poljščine. Založba Kmečki glas, Ljubljana 2015:105-110.

26. Ma QH, Wang X, Li HB, Li HG, Zhang FS, Rengel Z, Shen JB. Comparing localized application of different $\mathrm{N}$ fertilizer species on maize grain yield and agronomic $\mathrm{N}$-use efficiency on a calcareous soil. Field. Crop. Res. 2015;180:72-79.

27. Martini E, Buyer JS, Bryant DC, Hartz TK, Denison RF. Yield increases during the organic transition: improving soil quality or increasing experience? Field Crops Res. 2004;86:255-266.

28. Meier MS, Stoessel F, Jungbluth N, Juraske R, Schader C, Stolze M. Environmental impacts of organic and conventional agricultural products - Are the differences captured by life cycle assessment? J. Environ. Manag. 2015;149:193-208.

29. Ministry of Agriculture, Forestry and Food RS (MKGP). 2006. Pravilnik o ekološki pridelavi in predelavi kmetijskih pridelkov oziromaživil.http://www.uradni-list.si/1/ objava.jsp?urlid=2006128\&stevilka=5415 (09.08.2017).

30. Ministry of Agriculture, Forestry and Food RS (MKGP). 2008. Zakon o kmetijstvu. https://www.uradni-list.si/ glasilo-uradni-list-rs/vsebina?urlid=200845\&stevilka $=1$ 978 (04.09.2017).

31. Ministry of Agriculture, Forestry and Food RS (MKGP). 2010. Pravilnik o integrirani pridelavi poljščin. https://www.uradni-list.si/glasilo-uradni-list rs/vsebina/101725\#!/ Pravilnik-o-integrirani-pridelavipoljscin (09.08.2017).

32. Ministry of Agriculture, Forestry and Food RS (MKGP). 2012a. Zakon o kmetijstvu. https://www.uradni-list.si/ glasilo-uradni-list-rs/vsebina/109499 (04.09.2017).

33. Ministry of Agriculture, Forestry and Food RS (MKGP). 2012b. Zakon o kmetijstvu. https://www.uradni-list.si/ glasilo-uradni-list-rs/vsebina/2012-01-3528? sop=2012013528 (04.09.2017).

34. Ministry of Agriculture, Forestry and Food RS (MKGP). 2013. Tehnološka navodila za integrirano pridelavo poljščin http://www.mkgp.gov.si/fileadmin/mkgp.gov.si/ pageuploads/podrocja/Kmetijstvo/Integrirana_pridelava/TN_poljscine_2013.pdf (09.08.2017).

35. Ministry of Agriculture, Forestry and Food RS (MKGP). 2014a. Zakon o kmetijstvu. https://www.uradni-list.si/ glasilo-uradni-list-rs/vsebina/2014-01-1069?sop=201401-1069 (04.09.2017).

36. Ministry of Agriculture, Forestry and Food RS (MKGP). 2014b. Tehnološka navodila za integrirano pridelavo poljščin. http://www.mkgp.gov.si/fileadmin/mkgp. gov.si/pageuploads/podrocja/Kmetijstvo/Integrirana pridelava/TN_poljscine_2014.pdf (09.08.2017).

37. Ministry of Agriculture, Forestry and Food RS (MKGP). 2014c. http://www.mkgp.gov.si/si/delovna_podrocja/ kmetijstvo/integrirana_pridelava/tehnoloska_navodila/ (09.08.2017).

38. Muller A, Ferré M, Engel S, Gattinger, Holzkämperf A, Huberg R, Müllerh M, Six J. Nemecek T, Dubois D, Huguenin-Elie O, Gaillard G. Life cycle assessment of Swiss farming systems: I. Integrated and organic farming. Agric. Syst. 2011;104:217-232.

39. Muller A, Ferré M, Engel S, Gattinger A, Holzkämper A, Huber R, Müller M, Sixi J. Can soil-less crop production be a sustainable option for soil conservation and future agriculture? Land Use Policy 2017;69:102-105.

40. National Meteorological Service (ARSO). 2017. RS Ministrstvo za okolje in prostor.http://www.arso.gov.si/o\%20 agenciji/knji\%c5\%benica/mese\%c4\%8dni\%20bilten/ (04.08.2017).

41. Nemecek T, Dubois D, Huguenin-Elie O, Gaillard G. Life cycle assessment of Swiss farming systems: I. Integrated and organic farming. Agric. Syst. 2011a;104(3):217232.

42. Pfiffner L, Mäder P. Effects of biodynamic, organic and conventional production systems on earthworm populations. Biol. Agric. Hortic. 1997;15:3-10.

43. Pingali PL. Green Revolution: Impacts, limits, and the path ahead. P. Natl. Acad. Sci. USA. 2012;109(31):1230281230.

44. Ren T, Li H, Lu J, Bu R, Li X, Cong R, Lu M. Crop rotation-dependent yield responses to fertilization in winter oilseed rape (Brassica napus L.). Crop J. 2015;3(5):396404.

45. Rochester IJ, Constable GA. Improvements in nutrient uptake and nutrient use-efficiency in cotton cultivars released between 1973 and 2006. Field Crop. Res. 2015;173:14-21.

46. Scharp HC, Wehrmann J. Die Bedeutung des Mineralstickstoffvorrates des Bodens zu Vegetationsbeginn für die N-Düngung zu Winterweizen. Landwirtschaftliche Forschung 1975;32:100-114.

47. Seufert V, Ramankutty N, Foley JA. Comparing the yields of organic and conventional agriculture. Nature 2012;485:229-232.

48. Shah A, Askegaard M, Rasmussen IA, Cordoba J, Eva M, Olesen JE. Productivity of organic and conventional arable cropping systems in long-term experiments in Denmark. Eur. J. Agron. 2017;90:12-22.

49. Silgram M, Shepherd M. The effects of cultivation on soil nitrogen mineralization. Adv. Agron. 1999;65:267-311.

50. Smith P, Haberl H, Popp A, Erb KH, Lauk C, Harper R, Tubiello F, de Siqueira Pinto A, Jafari M, Sohi S, Masera O, Böttcher H, Berndes G, Bustamante M, Ahammad $\mathrm{H}$, Clark H, Dong HM, Elsiddig EA, Mbow C, Ravindranath NH, Rice CW, Robledo Abad C, Romanovskaya 
A, Sperling F, Herrero M, House JI, Rose S. How much land based greenhouse gas mitigation can be achieved without compromising food security and environmental goals? Glob. Change Biol. 2013;19:2285-2302.

51. Specht K, Siebert R, Hartmann I, Freisinger UB, Sawicka M, Werner A, Thomaier S, Henckel D, Walk H, Dierich A. Urban agriculture of the future: an overview of sustainability aspects of food production in and on buildings. Agric. Hum. Values 2014;31:33-51.

52. Statgraphics (Release Centurion XV) StatPoint, Inc., 2005.

53. Statistical Office of the Republic of Slovenia (SURS). 2017. SI-STAT Data Portal - Environment and natural resources. Available at: http://pxweb.stat.si/ pxweb/ Dialog/varval.asp? $\mathrm{ma}=1502402 \mathrm{E} \& \mathrm{ti}=\& \mathrm{path}=$. . $/$ Database/Environment/15_agriculture_fishing/04_crop_ production/01_15024_crops_area/\&lang=1/ (8.9.2017).

54. Štraus S. Potential indicators for sustainability assessment of food production on the field level [dissertation]. Maribor: Faculty of Agriculture and Life Sciences, University of Maribor, 2012.

55. Touliatos D, Dodd IC, McAinsh M. Vertical farming increases lettuce yield per unit area compared to conventional horizontal hydroponics. Food Energy Secur. 2016;5(3):184-191.

56. Turinek M. Comparability of the Biodynamic Production System Regarding Agronomic, Environmental and
Quality Parameters [dissertation]. Maribor: Faculty of Agriculture and Life Sciences, University of Maribor, 2011.

57. United States Department of Agriculture (USDA). 2017. Conservation Service Soils Textural Classification System. https:/www.nrcs.usda.gov/wps/portal/nrcs/detail/ soils/survey/?cid=nrcs142p2_054167 (14.8.2017).

58. Vukmanič T. Ecological footprint of field crops and vegetables depending on production system [M. Thesis]. Maribor: Faculty of Agriculture and Life Sciences, University of Maribor, 2016.

59. Wall DH, Nielsen UN, Six J. Soil biodiversity and human health. Nature 2015; 528: 69-76.

60. Wien HC. The Cucurbits: Cucumer, Melon, Squash and Pumpkin. In: The Physiology of Vegetable Crops. CAB International, Wallingford, 1997.

61. Williams PRD, Hammitt JK. Perceived risks of conventional and organic produce. Pesticides, pathogens, and natural toxins. Risk Anal. 2001;21(2): 319-330.

62. Xu XP, Liu XY, He P, Johnston AM, Zhao SC, Qiu SJ, Zhou W. Yield gap, indigenous nutrient supply and nutrient use efficient for maize in China. PLoS One 2015:10:1-12.

63. Zhou W. Establishing a scientific basis for fertilizer recommendations for wheat in China: Yield response and agronomic efficiency. Field Crops Res. 2013;140:1-8.

\section{Vpliv pridelovalnih sistemov in sort oljnih buč (Cucurbita pepo L. group Pepo) na pridelek ter agronomsko učinkovitost hranil}

\section{IZVLEČEK}

V letih 2013 in 2014 smo na trajnostnem poskusu, ki poteka na lokaciji Univerzitetnega kmetijskega centra Pohorski dvor že od leta 2007, z različnimi pridelovalnimi sistemi (konvencionalni, integrirani, ekološki, biodinamični) izvedli poljski poskus. Namen raziskave je bil preučiti vplive različnih pridelovalnih sistemov, sort (hibridna in populacijska sorta) ter leta na pridelavo oljnih buč. Tehnike pridelave so bile izvedene v skladu z veljavno zakonodajo in standardi za posamezni pridelovalni sistem. $\mathrm{V}$ času setve, pred dognojevanjem $\mathrm{v}$ začetku junija in ob spravilu pridelka smo analizirali količino mineralnega dušika $\mathrm{v}$ tleh. Vrednotili smo število in maso dozorelih, nedozorelih in propadlih plodov buč, pridelek bučnic ter izračunali agronomsko učinkovitost dodanih hranil. Sklepamo, da imajo leto, pridelovalni sistem in sorta statistično značilen vpliv na oblikovanje pridelka in pridelek bučnic. Na količino mineralnega dušika v tleh v maju in septembru vplivata pridelovalni sistem in leto, $\mathrm{v}$ juniju le pridelovalni sistem. Hibridna sorta oblikuje večji pridelek bučnic v vseh pridelovalnih sistemih, tudi v neugodnih rastnih razmerah posameznega leta. Agronomska učinkovitost dodanih hranil v biodinamičnem in ekološkem pridelovalnem sistemu je, v primerjavi s konvencionalnim, večja ali enaka, podobno velja za hibrid v primerjavi s starejšo sorto. Ob primerljivi oskrbi oljnih buč s hranili in kakovostno izvedbo pridelovalnih ukrepov v povezavi z novejšo sorto, lahko tudi v biodinamičnem in ekološkem načinu kmetovanja pričakujemo primerljive pridelke buč in bučnic v primerjavi z manj trajnostno naravnanimi sistemi pridelave, ki v naravi mnogokrat povzročajo škodo.

Ključne besede: pridelovalni sistemi, sorta/hibrid, oljna buča, mineralni dušik, agronomska učinkovitost, pridelek. 